\title{
Identification of Soybean mosaic virus Strains by RT-PCR/RFLP Analysis of Cylindrical Inclusion Coding Region
}

Yul-Ho Kim, National Institute of Crop Science, RDA, Suwon 441-857 Korea; Ok-Sun Kim, National Seed Management Office, MAF, Suwon 442-400, Korea; Jae-Hwan Roh, Jung-Kyung Moon, and Soo-In Sohn, National Institute of Crop Science; Sang-Chul Lee, Department of Agronomy, Kyungpook National University, Taegu 702701, Korea; and Jang-Yong Lee, National Institute of Crop Science

\begin{abstract}
Kim, Y.-H., Kim, O.-S., Roh, J.-H., Moon, J.-K., Sohn, S.-I., Lee, S.-C., and Lee, J.-Y. 2004 Identification of Soybean mosaic virus strains by RT-PCR/RFLP analysis of cylindrical inclusion coding region. Plant Dis. 88:641-644.

A reverse-transcriptase polymerase chain reaction/restriction fragment length polymorphism (RT-PCR/RFLP) was employed successfully for detection and identification of Soybean mosaic virus (SMV) strains. A primer pair amplifying a 1,385-bp fragment of the cylindrical inclusion (CI) coding region was used for RT-PCR and the RFLP profiles of the RT-PCR products were compared after restriction digestion with $R s a \mathrm{I}, E c o \mathrm{RI}$, or $A c c \mathrm{I}$ restriction endonucleases. These enzymes were chosen based on the nucleotide sequences of SMV strains G2, G5, G5H, G7, and $\mathrm{G} 7 \mathrm{H}$ in the $\mathrm{CI}$ coding region. These five strains, as well as seedborne SMV isolates from local soybean cultivars, could be differentiated by RT-PCR/RFLP analysis. The results correlated well with strain identification by symptom phenotypes produced on differential cultivars inoculated with strains and isolates. The sensitivity of RT-PCR enabled detection of SMV from plants with necrotic symptoms in which the number of virus particles was too low to be detected by enzyme-linked immunosorbent assay.
\end{abstract}

Soybean mosaic virus (SMV) belongs to the virus family Potyviridae (17). More than eight SMV strains exist in Korea (9). Detection and identification of SMV strains is very important both for soybean cultivation and breeding SMV-resistant cultivars. Although Forrest et al. (13) succeeded in discriminating SMV strain G5 from non-G5 SMV isolates using strainspecific monoclonal antibodies, they had to use three antibodies because a single monoclonal antibody that could detect a single strain had not been identified. It is still difficult to differentiate SMV strains by serological methods because most SMV strains are serologically homogeneous $(5,14,18)$. Also, it is not easy to raise strainspecific antibodies. Therefore, the method based on the pathogenicity of SMV isolates on differential soybean cultivars $(1,2,10)$ has been used widely to identify SMV strains. However, using differential cultivars is laborious and time consuming.

Reverse-transcriptase polymerase chain reaction (RT-PCR) is widely used in the

Corresponding author: J.-Y. Lee

E-mail: jangylee@rda.go.kr

Part of this work was supported by a grant from BioGreen 21 Program, Rural Development Administration, Republic of Korea.

Accepted for publication 21 January 2004.

Publication no. D-2004-0322-02R

(C) 2004 The American Phytopathological Society detection of plant viruses $(4,11)$. RT-PCR, when combined with restriction fragment length polymorphism (RFLP), becomes a more powerful technique to differentiate virus $(7,16)$ and fungal strains (6). Recently, Letschert et al. (12) reported that serologically related Tobamovirus spp. could be differentiated with either RTPCR/RFLP or RT-PCR using species-specific primers.

The complete nucleotide sequences of SMV strain G2 and G7 have been determined (8) and most of the variation was observed in $\mathrm{P} 1$, helper component-protease (HC-Pro), P3, and cylindrical inclusion (CI) regions. Omunyin et al. (15) first used RT-PCR assay to detect and discriminate two SMV strains, G2 and G7. They have shown that unique RNA-specific primers can be employed to detect and discriminate between RNAs of very similar strains. In a previous study (10), we reported the nucleotide sequences of the $\mathrm{CI}$ region of SMVs G5, G5H, and G7H in and compared the sequence with those of SMVs G2 and G7. It also was found that the simple RT-PCR could not differentiate other strains such as G7H, G5H, and G5 from G7. The genome sequences of these strains were analyzed further and it was suggested that RFLP analyses after amplifying the RNAs could help to differentiate these strains. The objective of this study was to determine whether a simple RT-PCR combined with RFLP analysis for the CI coding region can substitute for the laborious and time-consuming method using differ- ential cultivars to detect and differentiate SMV strains.

\section{MATERIALS AND METHODS}

SMV strains and isolates. Five SMV strains (G2, G5, G5H, G7, and G7H) were used in this study. SMV G7 (PV-613) was obtained from the American Type Culture Collection (Manassas, VA). SMV G5H was obtained from E. K. Cho (Andong National University, Korea). SMV G2 and G5 were seedborne isolates collected from local soybean cultivars and SMV G7H was isolated from a soybean field in Korea. Each strain was confirmed by inoculation on the differential soybean cultivars (2) and Korean soybean cultivars such as Hwangkeumkong, Daewonkong, Duyoukong, and Myeongjunamulkong. Eight seedborne SMV isolates collected from local cultivars also were tested and differentiated.

Virulence tests. Each SMV strain used in this study was maintained in soybean cv. Kwangankong (Suwon 159). Inoculum was prepared by homogenizing symptomatic leaves in $0.01 \mathrm{M}$ sodium phosphate buffer (pH 7.0, $5 \mathrm{ml} / \mathrm{g}$ of leaf tissue) with a chilled mortar and pestle. Inoculations were made by rubbing inoculum-soaked cotton swabs on fully expanded primary leaves predusted with Carborundum powder, after which the leaves were rinsed immediately with tap water. All inoculations of SMV strains were performed in greenhouse at average daily minimum and maximum temperatures of 20 and $32^{\circ} \mathrm{C}$, respectively.

Total RNA extraction and RTPCR/RFLP. Viral RNA was isolated using the RNA isolation system (Promega Corp., Madison, WI) according to the manufacturer's instructions. A pair of oligonucleotides amplifying a 1,385-bp fragment at positions from 4,176 to 5,560 , including the CI coding region, were designed based on the sequence published by Jayaram et al. (8). The forward primer, CI5' (5'GCATTCAACTGTGCGCTTAAAGAAT$3^{\prime}$ ), was homologous to nucleotides 4,176 to 4,200 and the reverse primer, $\mathrm{CI}^{\prime}{ }^{\prime}\left(5^{\prime}\right.$ TTGAGCTGCAAAAATTTACTCACTT$3^{\prime}$ ), was complementary to nucleotides 5,536 to 5,560 of SMV strain G2. RT-PCR was performed in $50-\mu l$ reaction mixtures containing $10 \mu \mathrm{l}$ of AMV/Tfi $5 \times$ reaction buffer, $1 \mu \mathrm{l}$ of dNTP mix (10 mM each), 
Table 1. Predicted size after digestion with EcoRI, RsaI, or AccI of the amplified 1,385-bp fragment of five Soybean mosaic virus (SMV) strains ${ }^{\mathrm{a}}$

\begin{tabular}{|c|c|c|c|c|c|}
\hline \multirow[b]{2}{*}{ Restriction enzymes } & \multicolumn{5}{|c|}{ SMV strains $(\mathbf{b p})^{\mathbf{b}}$} \\
\hline & G7H & G5H & G5 & G7 & G2 \\
\hline \multirow[t]{5}{*}{$\overline{E c o R I}$} & 1,303 & $\ldots$ & $\ldots$ & $\ldots$ & $\ldots$ \\
\hline & $\ldots$ & & & $\ldots$ & 891 \\
\hline & $\ldots$ & 802 & 802 & 802 & $\ldots$ \\
\hline & $\ldots$ & 501 & 501 & 501 & $\ldots$ \\
\hline & & $\ldots$ & $\ldots$ & $\ldots$ & 412 \\
\hline \multirow[t]{9}{*}{ RsaI } & 1,226 & $\ldots$ & $\ldots$ & $\ldots$ & 1,226 \\
\hline & $\ldots$ & 1,048 & $\ldots$ & $\ldots$ & $\ldots$ \\
\hline & $\ldots$ & $\ldots$ & $\ldots$ & 761 & $\ldots$ \\
\hline & $\ldots$ & $\ldots$ & 586 & $\ldots$ & $\ldots$ \\
\hline & $\ldots$ & $\ldots$ & 462 & $\ldots$ & $\ldots$ \\
\hline & $\ldots$ & $\ldots$ & $\ldots$ & 287 & $\ldots$ \\
\hline & $\ldots$ & 178 & 178 & 178 & $\ldots$ \\
\hline & $\ldots$ & 159 & 159 & 159 & 159 \\
\hline & 146 & $\ldots$ & $\ldots$ & $\ldots$ & 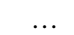 \\
\hline \multirow[t]{4}{*}{$A c c \mathrm{I}$} & 1,385 & $\ldots$ & $\ldots$ & 1,385 & 1,385 \\
\hline & $\ldots$ & 709 & 709 & $\ldots$ & $\ldots$ \\
\hline & $\ldots$ & 446 & 446 & $\ldots$ & $\ldots$ \\
\hline & $\ldots$ & 230 & 230 & $\ldots$ & $\ldots$ \\
\hline
\end{tabular}

${ }^{a}$ Bands smaller than $100 \mathrm{bp}$ were not shown.

b GenBank accession numbers: G7H, AY169283; G5H, AY169284; G5, AY169285; G7, AF241739; and $\mathrm{G} 2$, S42280.
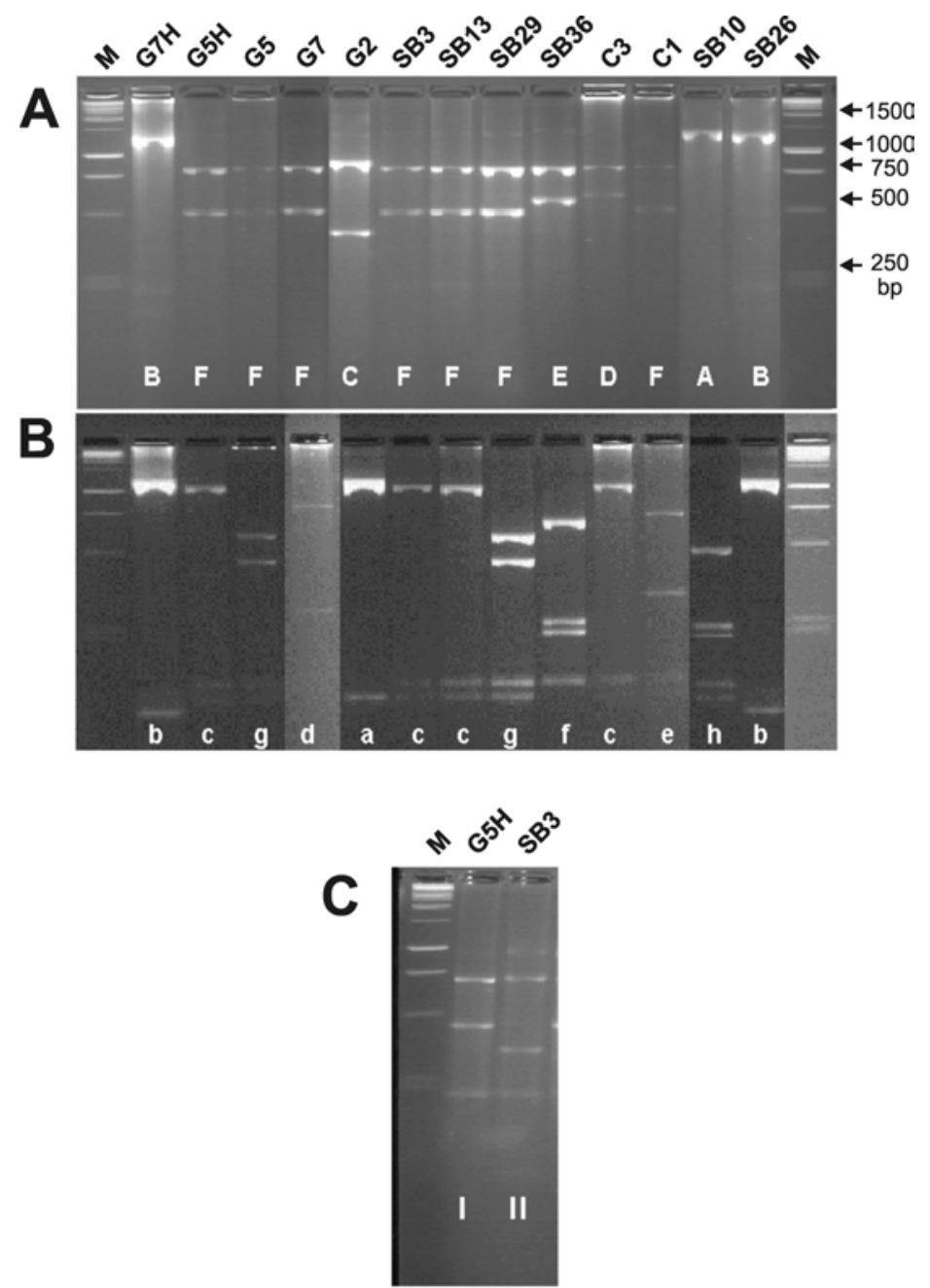

Fig. 1. The reverse-transcriptase polymerase chain reaction products of Soybean mosaic virus (SMV) strains and isolates after restriction enzyme digestion with EcoRl, Rsal, or Accl, separated by 4\% Nusieve 3:1 agarose gel electrophoresis and visualized by ethidium bromide under UV light. A, EcoRl digestion; the restriction fragment length polymorphism (RFLP) patterns of each strain were assigned to one of six groups (A-F) as shown at the bottoms of the lane. B, Rsal digestion gave eight different RFLP patterns (a-h). C, Accl digestion of G5H (I) and SB3 (II) showed different RFLP patterns. The 13 SMV strains and isolates were differentiated based on the RFLP profiles as follows: G7H (B, b), G5H (F, c, I), G5 (F, g), G7 (F, d), G2 (C, a), SB3 (F, c, II), SB13 (F, c), SB29 (F, g), SB36 (E, f), C3 (D, c), C1 (F, e), SB10 (A, h), and SB26 (B, b).
$2 \mu \mathrm{l}$ of $\mathrm{MgSO}_{4}(25 \mathrm{mM}), 1 \mu \mathrm{l}$ of each primer $(50 \mathrm{pmol}), 1 \mu \mathrm{l}$ of AMV reverse transcriptase ( 5 units/ $\mu \mathrm{l}), 1 \mu \mathrm{l}$ of Tfi DNA polymerase ( 5 units $/ \mu \mathrm{l}$ ), and $5 \mu \mathrm{l}$ of template RNA. Thermocycling was programmed as follows: cDNA synthesis at $48^{\circ} \mathrm{C}$ for $45 \mathrm{~min}$ and $\mathrm{RNA} / \mathrm{cDNA} /$ primer denaturation at $94^{\circ} \mathrm{C}$ for $2 \mathrm{~min}$, followed by 40 cycles for template denaturation at $94^{\circ} \mathrm{C}$ for $30 \mathrm{~s}$, primer annealing at $60^{\circ} \mathrm{C}$ for $1 \mathrm{~min}$, and extension at $68^{\circ} \mathrm{C}$ for $2 \mathrm{~min}$; and a final extension at $68^{\circ} \mathrm{C}$ for $7 \mathrm{~min}$. The amplified products were separated by $1.2 \%$ agarose gel electrophoresis. After precipitation with ethanol and $3 \mathrm{M}$ sodium acetate and collection by centrifugation, the PCR products were resuspended in nuclease-free water. The PCR products then were digested with restriction enzymes EcoRI, RsaI, or AccI separated in a 4\% Nusieve 3:1 agarose gel (FMC; FMC Bioproducts, Rockland, ME) containing ethidium bromide. The RFLP bands were visualized with an UV transilluminator.

\section{RESULTS}

The predicted RFLP profile of amplified fragments based on the nucleotide sequences of SMV strains reported by Jayaram et al. (8) and Kim et al. (10) is presented in Table 1. Although there were many possible restriction endonucleases (REs) to be used for RFLP analysis, three REs, EcoRI, RsaI, and $A c c \mathrm{I}$, were presented here. EcoRI differentiated G2 and G7 strains, whereas $R s a$ I differentiated all five strains. AccI also was chosen because this enzyme differentiated $\mathrm{G} 5 \mathrm{H}$ from an isolate identified as a G3 strain based on the responses of soybean differentials.

The RT-PCR/RFLP result (Fig. 1) confirmed the predictions presented in Table 1. EcoRI digestion of the amplified fragment gave three different RFLP patterns for the five SMV strains (Fig. 1). RsaI restriction digestion also showed the expected banding patterns and differentiated the five SMV strains. The RT-PCR/RFLP patterns of eight seedborne SMV isolates collected from local soybean cultivars were compared with those five reference strains (Fig. 1). Based on the band patterns, the 13 SMV (5 strains and 8 isolates) could be grouped into six or eight groups when restriction digested with EcoRI or RsaI, respectively. From the RT-PCR/ RFLP results and the phenotypic reaction of soybean differentials to SMV strains (Table 2), the SMV isolates SB13, SB26, and SB29 were classified as G5H, G7H, and G5, respectively. The SMV isolates C3, SB10, and SB36 (Table 2, "unknown") caused different phenotypic reactions on soybean differentials from previously identified strains and showed different RFLP patterns from other SMV strains. Two isolates, $\mathrm{C} 1$ and $\mathrm{SB} 3$, which produced the same phenotypic reactions on the soybean differential as the G3 strain, showed different RFLP patterns from each other. C1 
showed a peculiar RFLP pattern that was different from the SMV strains and isolates tested; whereas SB3 showed the same pattern as the G5H strain when EcoRI and $R s a \mathrm{I}$ REs were used. The isolate SB3 could be distinguished from G5H by AccI digestion (Fig. 1C).

\section{DISCUSSION}

Detection and identification of SMV strains is very important both for soybean cultivation and breeding SMV-resistant cultivars. Nevertheless, the most widely used method for SMV differentiation, which uses differential soybean cultivars, is laborious and time consuming. RT-PCR combined with RFLP could be a useful method to replace many of these troublesome procedures. In this method, a part of the CI coding region of SMV genome was amplified, restriction digested, and separated on an agarose gel. Five SMV strains and eight isolates could be clearly differentiated by this method (Fig. 1) and the results obtained from the screening method using differential cultivars also support the results that RT-PCR/RFLP (Table 2) is reliable for the detection and identification SMV isolates. Five SMV strains (G2, G5, $\mathrm{G} 5 \mathrm{H}, \mathrm{G} 7$, and $\mathrm{G} 7 \mathrm{H}$ ) used in this study could clearly be differentiated by amplifying CI coding region at position 4,176 to 5,560 and restriction digestion with $R s a \mathrm{I}$. Seedborne field isolates collected from local soybean cultivars also could be differentiated.

RT-PCR/RFLP differentiated SMV strains that could not be distinguished by the screening method using differential cultivars. For example, isolates SB3 and $\mathrm{C} 1$ were identified as G3 at first by screening using differential cultivars, but these two isolates showed different RT-PCR/ RFLP patterns (Fig. 1). Further screening by differential cultivars could distinguish these isolates because $\mathrm{C} 1$ caused partial necrosis on Ogden, whereas SB3 caused complete necrosis on the same cultivar (Table 2). Three isolates, C3, SB10, and SB36, were designated as unknown because they didn't show the same reaction on differential cultivars as the reference strains. All three isolates also showed RFLP patterns that differed from the refer- ence strains. This means the RT-PCR/ RFLP method used here could be applied for detection and differentiation of any new or unidentified SMV isolates as a quick and efficient screening method. It was very difficult to isolate and identify SMVs from leaves showing necrotic symptom by directly inoculating differential cultivars because the number of virus particles was low. Sometimes it was necessary to inoculate susceptible cultivars to increase the viruses before screening with differential cultivars. In this case, RTPCR/RFLP would be an efficient tool for detecting and identifying SMV strains because RT-PCR is such a sensitive technique that requires only tiny amounts of RNA. The G7H and G5H strains typically cause necrotic symptoms on many Korean cultivars (10) and are not easily detected or isolated by inoculating directly on the differential cultivars. Twenty SMV isolates showing RT-PCR/RFLP banding patterns identical to G7H or G5H were inoculated on differential cultivars and confirmed as G7H or G5H (data not shown).
The usefulness of RT-PCR/RFLP for differentiating SMV strains also was confirmed by predicting the RFLP profile of the five SMV strains N, HZ, HH5, Aa and CN18, which were deposited in, GenBank (Table 3). By comparing the sequence of the 1,385-bp region, it is predicted that the 4 SMV strains HZ, HH5, Aa, and CN18 could be differentiated from the 13 SMV strains already identified by digestion with EcoRI and RsaI REs. The SMV N strain, an isolate of strain G2 (3), which is predicted to show the same banding patterns as SMV G2 when the three REs EcoRI, $R s a \mathrm{I}$, or $A c c \mathrm{I}$ are used (Tables 1 and 3), could be differentiated from the G2 strain if more REs, such as HaeII, HindII, HpaII, and BsaAI, are employed (data not shown). Considering that there is $99 \%$ nucleotide sequence homology in the amplified 1,385-bp region between these two strains, the RT-PCR/RFLP method is proven to be a powerful method for differentiating SMV strains.

Even though all SMV strains were not examined by RT-PCR/RFLP assay, the

Table 3. Predicted size of the amplified 1,385-bp fragment of five other Soybean mosaic virus (SMV) strains deposited in GenBank after digestion with EcoR1, Rsal, or Accl ${ }^{\mathrm{a}}$

\begin{tabular}{|c|c|c|c|c|c|}
\hline \multirow[b]{2}{*}{ Restriction enzymes } & \multicolumn{5}{|c|}{ SMV strains $(\mathbf{b p})^{\mathbf{b}}$} \\
\hline & $\mathbf{N}$ & $\mathbf{H Z}$ & HH5 & Aa & CN18 \\
\hline \multirow[t]{6}{*}{ EcoRI } & $\ldots$ & $\ldots$ & $\ldots$ & $\ldots$ & 1,385 \\
\hline & $\ldots$ & 1,303 & 1,303 & $\ldots$ & $\ldots$ \\
\hline & 891 & $\ldots$ & $\ldots$ & $\ldots$ & $\ldots$ \\
\hline & $\ldots$ & $\ldots$ & $\ldots$ & 802 & $\ldots$ \\
\hline & & $\ldots$ & $\ldots$ & 583 & $\ldots$ \\
\hline & 412 & $\ldots$ & & $\ldots$ & $\ldots$ \\
\hline \multirow[t]{9}{*}{ RsaI } & 1,226 & $\ldots$ & 1,226 & $\ldots$ & $\ldots$ \\
\hline & $\ldots$ & 1,048 & $\ldots$ & $\ldots$ & $\ldots$ \\
\hline & $\ldots$ & $\ldots$ & $\ldots$ & $\ldots$ & 953 \\
\hline & $\ldots$ & $\ldots$ & $\ldots$ & 516 & $\ldots$ \\
\hline & $\ldots$ & $\ldots$ & $\ldots$ & 275 & $\ldots$ \\
\hline & $\ldots$ & $\ldots$ & $\ldots$ & 257 & $\ldots$ \\
\hline & $\ldots$ & $\ldots$ & $\ldots$ & $\ldots$ & 224 \\
\hline & $\ldots$ & 178 & $\ldots$ & 178 & \\
\hline & 159 & 159 & 159 & 159 & 159 \\
\hline \multirow[t]{5}{*}{$A c c \mathrm{I}$} & 1,385 & $\ldots$ & $\ldots$ & $\ldots$ & $\ldots$ \\
\hline & $\ldots$ & 939 & 939 & 939 & $\ldots$ \\
\hline & $\ldots$ & $\ldots$ & $\ldots$ & $\ldots$ & 709 \\
\hline & $\ldots$ & 446 & 446 & 446 & 446 \\
\hline & $\ldots$ & $\ldots$ & $\ldots$ & $\ldots$ & 230 \\
\hline
\end{tabular}

${ }^{a}$ Bands smaller than $100 \mathrm{bp}$ were not shown.

b GenBank accession numbers: N, D00507; HZ, AJ312439; HH5, AJ310200; Aa, AB100442; and CN18, AJ619757.

Table 2. Phenotypic reactions of soybean differentials to Soybean mosaic virus (SMV) strains and SMV isolates from seedborne local cultivars

\begin{tabular}{|c|c|c|c|c|c|c|c|c|c|c|c|c|c|}
\hline \multirow[b]{2}{*}{ Differential cultivars } & \multicolumn{13}{|c|}{ Symptoms caused by SMV strains ${ }^{a}$} \\
\hline & G7H & G5H & G5 & G7 & G2 & SB 3 & SB 13 & SB 29 & SB 36 & $\mathbf{C 3}$ & $\mathrm{C} 1$ & SB 10 & SB 26 \\
\hline Clark & $-/ \mathrm{M}$ & $-/ \mathrm{M}$ & $-/ \mathrm{M}$ & $-/ \mathrm{M}$ & $-/ \mathrm{M}$ & $-/ \mathrm{M}$ & $-/ \mathrm{M}$ & $-/ \mathrm{M}$ & $-/ \mathrm{M}$ & $-/ \mathrm{M}$ & $-/ \mathrm{M}$ & $-/ \mathrm{M}$ & $-/ \mathrm{M}$ \\
\hline Davis & $-/ \mathrm{M}$ & $-/ \mathrm{M}$ & $-/ \mathrm{M}$ & $-/ \mathrm{M}$ & $-1-$ & $-1-$ & $-/ \mathrm{M}$ & $-/ \mathrm{M}$ & $-1-$ & $-/ \mathrm{M}$ & $-1-$ &,$- \mathrm{L} / \mathrm{M}$ & $-/ \mathrm{M}$ \\
\hline York & $-/ \mathrm{M}$ & $-/ \mathrm{M}$ & $-/ \mathrm{M}$ & $-/ \mathrm{M}$ & $-1-$ & $-1-$ & $-/ \mathrm{M}$ & $-/ \mathrm{M}$ & $-1-$ & $-/ \mathrm{M}$ & $-1-$ &,$- \mathrm{L} / \mathrm{M}$ & $-/ \mathrm{M}$ \\
\hline Marshall & $\mathrm{L} / \mathrm{N}$ & $-1-$ & $-1-$ & $\mathrm{L} / \mathrm{N}$ & $\mathrm{L} / \mathrm{N}$ & $\mathrm{L} / \mathrm{N}$ & $-1-$ & $-1-$ & $\mathrm{L} / \mathrm{N}$ & $\mathrm{L} / \mathrm{N},-$ & $\mathrm{L} / \mathrm{N}$ & $\mathrm{L} / \mathrm{N}$ & $\mathrm{L} / \mathrm{N}$ \\
\hline Ogden & $\mathrm{L} / \mathrm{N}$ & $-1-$ & $-1-$ & $\mathrm{L} / \mathrm{N}$ & $-1-$ & $\mathrm{L} / \mathrm{N}$ & $-1-$ & $-1-$ & $-1-$ & $\mathrm{L} / \mathrm{N},-$ & $\mathrm{L} / \mathrm{N},-$ & $\mathrm{L} / \mathrm{N}$ & $\mathrm{L} / \mathrm{N}$ \\
\hline Kwanggyo & $\mathrm{L} / \mathrm{N}$ & $\mathrm{L} / \mathrm{N}$ & $\mathrm{L} / \mathrm{N}$ & $\mathrm{L} / \mathrm{N}$ & $-1-$ & $-1-$ & $\mathrm{L} / \mathrm{N}$ & $\mathrm{L} / \mathrm{N}$ & $\mathrm{L} / \mathrm{N}$ & $\mathrm{L} / \mathrm{N},-$ & $-1-$ & $-1-$ & $\mathrm{L} / \mathrm{N}$ \\
\hline Buffalo & $\mathrm{L} / \mathrm{N}$ & $-1-$ & $-1-$ & $\mathrm{L} / \mathrm{N}$ & $-1-$ & $-1-$ & $-1-$ & $-1-$ & $\mathrm{L} / \mathrm{N}$ & $\mathrm{L} / \mathrm{N},-$ & $-1-$ & $-1-$ & $\mathrm{L} / \mathrm{N}$ \\
\hline Hwang-Keum & $\mathrm{L} / \mathrm{N}$ & $\mathrm{L} / \mathrm{N},-$ & $\mathrm{L} /-$ & $\mathrm{L} /-$ & $-1-$ & $-1-$ & $\mathrm{L} / \mathrm{N},-$ & $\mathrm{L} /-$ & $-1-$ & $\mathrm{L} / \mathrm{N},-$ & $-1-$ & $-1-$ & $\mathrm{L} / \mathrm{N}$ \\
\hline Strain & G7H & G5H & G5 & G7 & G2 & G3 & G5H & G5 & UK & UK & G3 & UK & $\mathrm{G} 7 \mathrm{H}$ \\
\hline
\end{tabular}

${ }^{\mathrm{a}}$ Reaction on inoculated primary leaves/reactions on uninoculated upper leaves; $-=$ symptomless; $\mathrm{M}=$ mosaic; $\mathrm{N}=$ necrosis; $\mathrm{L}=$ local lesions;,$- \mathrm{L}=$ symptomless or local lesions; $\mathrm{N},-=$ necrosis or symptomless; UK = unknown. 
results obtained so far suggest that this technique could be used widely for detection and differentiation of SMVs. In addition, the RT-PCR/RFLP method also could be applied to detect and differentiate SMV strains from doubly infected soybean plants by separating the mixed RFLP patterns.

\section{ACKNOWLEDGMENTS}

We thank E. K. Cho for kindly offering the SMV-G5H strain.

\section{LITERATURE CITED}

1. Cho, E. K., Choi, S. H., and Cho, W. T. 1983. Newly recognized Soybean mosaic virus mutants and sources of resistance in soybeans. Res. Rep. ORD Korea (S.P.M.U.). 25:18-22.

2. Cho, E. K. and Goodman, R. M. 1979. Strains of Soybean mosaic virus: classification based on virulence in resistant soybean cultivars. Phytopathology 69:467-470.

3. Hajimorad, M. R., and Hill, J. H. 1998. Rsv1mediated resistance against Soybean mosaic virus- $\mathrm{N}$ is hypersensitive response-independent at inoculation site, but has the potential to initiate a hypersensitive response-like mechanism. Mol. Plant Pathol. Interact. 14:587-598.

4. Henson, J. H., and French, R. 1993. The polymerase chain reaction and plant disease diagnosis. Annu. Rev. Phytopathol. 31:81-109.

5. Hill, J. H., Benner, H. I., and Van Deusen, R. A.
1994. Rapid differentiation of Soybean mosaic virus isolates by antigenic signature analysis. J. Phytopathol. 142:152-162.

6. Hong, S. B., Jee, H. J., Lee, S. I., and Go, S. J. 1999. Restriction fragment length polymorphism of PCR amplified ribosomal DNA among Korean isolates of Phytophthora. Plant Pathol. J. 15:228-235.

7. Jackwood, D. J., and Nielsen, C. K. 1997. Detection of infectious bursal disease viruses in commercially reared chickens using the reverse transcriptase/polymerase chain reactionrestriction endonuclease assay. Avian Dis. 41:137-143.

8. Jayaram, C., Hill, J. H., and Miller, W. A. 1992. Complete nucleotide sequences of two Soybean mosaic virus strains differentiated by response of soybean containing the $R s v$ resistance gene. J. Gen. Virol. 73:2067-2077.

9. Kim, Y. H., Kim, O. S., Lee, B. C., Im, D. J., and Choi, J. K. 2000. Distribution and diversity of soybean mosaic virus strains in Korea, Korean J. Plant Pathol. 16:179.

10. Kim, Y. H., Kim, O. S., Lee, B. C., Moon, J. K., Lee, S. C., and Lee, J. Y. 2003. G7H, a New Soybean Mosaic Virus Strain: Its Virulence and Nucleotide Sequence of CI Gene. Plant Dis. 87:1372-1375.

11. Langeveld, S. A., Dore, J. H., and Bol, J. F. 1991. Identification of potyviruses using polymerase chain reaction with degenerate primers. J. Gen. Virol. 72:1531-1541.
12. Letschert, B., Adam, G., Lesemann, D. E., Willingmann, P., and Heinze, C. 2002. Detection and differentiation of serologically crossreacting tobamoviruses of economical importance by RT-PCR and RT-PCR-RFLP. J. Virol Methods 106:1-10.

13. Nutter, F. W., Jr., Schultz, P. M., and Hill, J. H. 1998. Quantification of within-field spread of Soybean mosaic virus in soybean using strainspecific monoclonal antibodies. Phytopathology 88:895-901.

14. O'Connell-Ziegler, P., Benner, H. I., and Hill, J. H. 1986. Soybean mosaic virus; vecto specificity and coat protein properties. J. Phytopathol. 115:29-36.

15. Omunyin M. E., Hill J. H., and Miller W. A 1996. Use of unique RNA sequence-specific oligonucleotide primers for RT-PCR to detect and differentiate Soybean mosaic virus strains. Plant Dis. 80:1170-1174.

16. Qian, B., and Kibenge, F. S. B. 1996. Restriction fragment profiles of genome segment A of infectious bursal disease virus correlate with serotype and geographical origin of avibirnaviruses. Can. J. Microbiol. 42:93-97.

17. Shukla, D. D., Ward, C. W., and Brunt, A. A. 1994. The Potyviridae. CAB International, Wallingford, UK.

18. Soong, M. M., and Milbrath, G. M. 1980 Purification, partial characterization, and serological comparison of Soybean mosaic virus and its coat protein. Phytopathology 70:388 391. 